\title{
Efficacy of phytochemicals as immunomodulators in managing COVID-19: a comprehensive view
}

\author{
Sonali Bhattacharya ${ }^{1} \cdot$ Sudipta Majumdar Nee Paul ${ }^{1}$ (B)
}

Received: 11 September 2020/Accepted: 11 June 2021/Published online: 24 June 2021

(C) Indian Virological Society 2021

\begin{abstract}
Throughout history, disease outbreaks have worked havoc upon humanity, sometimes reorienting the history and at times, signaling the end of entire civilizations and the modern pandemic that the world is dealing with, is COVID-19 or SARS-CoV-2. A healthy immunity could be an ideal gear for resisting COVID-19 for neither medicines nor vaccines have been ascertained till date. In view of the present scenario, there is a demanding necessity to analyze innovative and valid techniques for forestalling and cure of COVID-19 by re-evaluating the structure of the natural compounds for drug designing. The Ayurveda has come forward by prescribing a lot of medicinal herbs for combating this dreaded disease. We have searched from sources in Pubmed and Google Scholar and found 1509 items. The search criteria were limited to the effect of phytochemicals in certain immunomodulatory aspects of viral infection. The original research papers related to the works on phytochemicals in the down regulation of NF-kB, activation of NK and CD8+ cells, inhibition of inflammatory cytokine release and ROS scavenging were included in our study. Here, we try to focus on the immunoregulatory cells which have a vital aspect in COVID-19 and highlight the potential effects of the restorative use of phytochemicals as drugs or dietary supplements.
\end{abstract}

Supplementary Information The online version contains supplementary material available at https://doi.org/10.1007/s13337021-00706-2.

Sudipta Majumdar Nee Paul

m.sudipta77@gmail.com

1 Department of Zoology, Rishi Bankim Chandra College, Naihati, West Bengal 743165, India
Keywords SARS-CoV-2 - Cytokines · Inflammation · Phytochemicals

\section{Introduction}

The world is currently dealing with the pandemic situation of COVID-19 caused by the novel corona virus i.e., SARSCoV-2. It has been proclaimed in the whole world except Antarctica. SARS-CoV-2 affects lower respiratory tract which can be fatal. Transmittal of this virus can take place by personal proximity with affected person via respiratory droplets which are greater than 5-10 micro meter or droplet nuclei when less than 5 micro meter in diameter and unintended exposure with areas in the surrounding domain or with articles used by the diseased person. There is some evidence that SARS-CoV-2 may bring about intestinal contamination and also found in faeces. However, it has not yet been reported for faecal-oral transmission of the virus. The patients experience a wide spread severity of the disease. While very few patients need care of hospital, the pronounced effects in these people are lethal in certain cases. The elderly person are more presumably to suffer than middle aged and younger ones due to their immunocompromised state of health.

The novel corona virus is a single stranded positive sense RNA containing entity having the envelope (E), spike $(\mathrm{S})$, nucleocapsid $(\mathrm{N})$ and membrane protein $(\mathrm{M})$, of which the spike and nucleocapsid proteins are obligatory in its life cycle [58]. The entry into the human cells is mainly facilitated by the binding of the Gln493 domain of the receptor binding motif of the spike protein to the host cell's ACE2 protein [67]. The replication process is quite complex upon entry into the host cell, which involves the action of the Replicase gene encoded enzyme by employing the 
negative strand of RNA for production of structural proteins of the viral progenies. The Nsp proteins aids in twisting the RNA while the $\mathrm{N}$ and $\mathrm{M}$ proteins bind to the genome and ER membrane respectively, preceding the transfer of the progenies to cell membrane for exocytosis [57].

Severe COVID-19 is induced not only by cellular impairment generated by the virus, but also by a reactive inflammatory storm that inflicts damage to the lungs and other organs. Acute respiratory distress syndrome (ARDS) follows after inflammation within lungs in severe COVID19 on average after about eight to nine from the appearance of initial symptoms [60] which is the main cause of respiratory failure and fatality. The ARDS caused by the viral infection exhibits an imperfectly regulated renin-angiotensin-aldosterone system (RAAS). As a result of unbalanced RAAS activity serum levels of Angiotensin II become high which upregulates the AgII-ATR1 axis. Due to this up regulation NF-kB, disintegrin and metalloprotease 17 are activated, causing the production of the two NF-kB stimulators i.e., EGFR ligand and TNF $\alpha$ [11]. IL6Amp is activated by Nf-KB and STAT3 after SARS-CoV2 infection, causing further damage such as multiple inflammatory and autoimmune diseases [32]. Hirano et al. proposed that the enhanced proinflammatory cytokines are induced by IL6Amp. ARDS is caused by the liberation of inflammation-inducing cytokines IL-1, IL-6 and TNF. The lungs of these patients is filled with a jelly [37] which may be hyaluronan whose defective production and regulation is related to ARDS [12]. It has been reported as well that these cytokines can induce HA synthase 2 in CD31+ endothelium, EpCAM+ lung alveolar epithelial cells, and fibroblasts [6].

The traditional knowledge of the use of phytochemicals as remedial measures in various diseases has been passed on from generations. It has been accepted due to certain beneficial properties such as nontoxicity, easy availability, and ability to be included in diet, less side effects as well as cost affectivity. They can provide a supportive therapy in addition to the prescribed broad-spectrum antibiotics. There have been evidences globally of the antiviral potencies of the phytochemicals. We have kept in mind these facts and attempted to review the potency of certain phytochemicals as immunomodulatory agents to boost up the immune health of a person for fighting with this disease.

\section{Method}

This Review was conducted keeping in front a question, whether phytochemicals play a role in modulating the Immune system for combating COVID-19. The source of our study included Google Scholar and Pubmed and 1509 studies related to our search were found. We then shortlisted those to 37 studies in accordance with Inclusion and Exclusion process (Fig. 1). The criteria taken into consideration were research studies involving the activities of phytochemicals respectively as immunomodulatory agents, studies involving active role of NK cells and CD8+ cells for production of anti-inflammatory cytokines and ROS scavenging activity and down regulation of NF-kB. The clinical trial studies associated with antiviral effects against respiratory viruses and SARS-CoV-2 were included in our criteria as well. The studies more than or equal to10 years old and other than Mammalian system were excluded.

\section{COVID-19 infection and immune system}

The virus alters the host's immunity in many aspects; lymphocytopenia, infective diagnostic markers like erythrocyte sedimentation rate, C-reactive protein, procalcitonin, and serum ferritin. Coexisting with this situation high levels of inflammation inducing cytokines and chemokines like tumor necrosis factor- $\alpha$ [TNF- $\alpha$ ], interleukin [IL]-2R, IL-6, IL 7, IL 10, G-CSF, IP 10, MCP-1and MIP 1A are observed. All these parameters were found to be elevated in extreme conditions in contrast with less severely infected people. In severely infected patients there is a significantly elevated level of CD14 + CD16+ cells in peripheral circulation as well as $\mathrm{FCN} 1+$ macrophage population in broncho-alveolar fluid leading to a surge in inflammatory cytokine and chemokine population [53]. The introductory defense mechanism against viral invasion includes IFN-I, which are recognized by the IFNAR receptors present at the plasma membrane in most cell types. The interaction of interferon with IFNAR prompts the phosphorylation of STAT1 causing their nuclear transposition and initiating activation of interferon-stimulated genes (ISG). Most ISGs are associated with inflammation and immunomodulation, hinder viral replication by stagnation of cell metabolism or cytokine secretion aiding in activation of the adaptive immunity. Delay in InterferonI signaling nurtures the cumulating of pathogenic inflammatory monocyte macrophages (IMMs), yielding exalted inflammatory cytokine/chemokine levels, vascular permeability, and weakened virus-specific adaptive immunity in SARS-CoV patients [8]. The analogy of novel corona virus with SARS-CoV and MERS-CoV prompts us to speculate that it utilizes a similar strategy to destabilize innate immune response.

Different viral proteins may alter different points of the interferon signaling route, which are likely to aid in replication of virus, and increased level of pyroptosis thus leading to anomalous inflammatory reaction [53]. Reports of accumulation of monocytes and $\mathrm{T}$ cells in the lungs, 
Fig. 1 Systematic chart to pinpoint all the selected publication

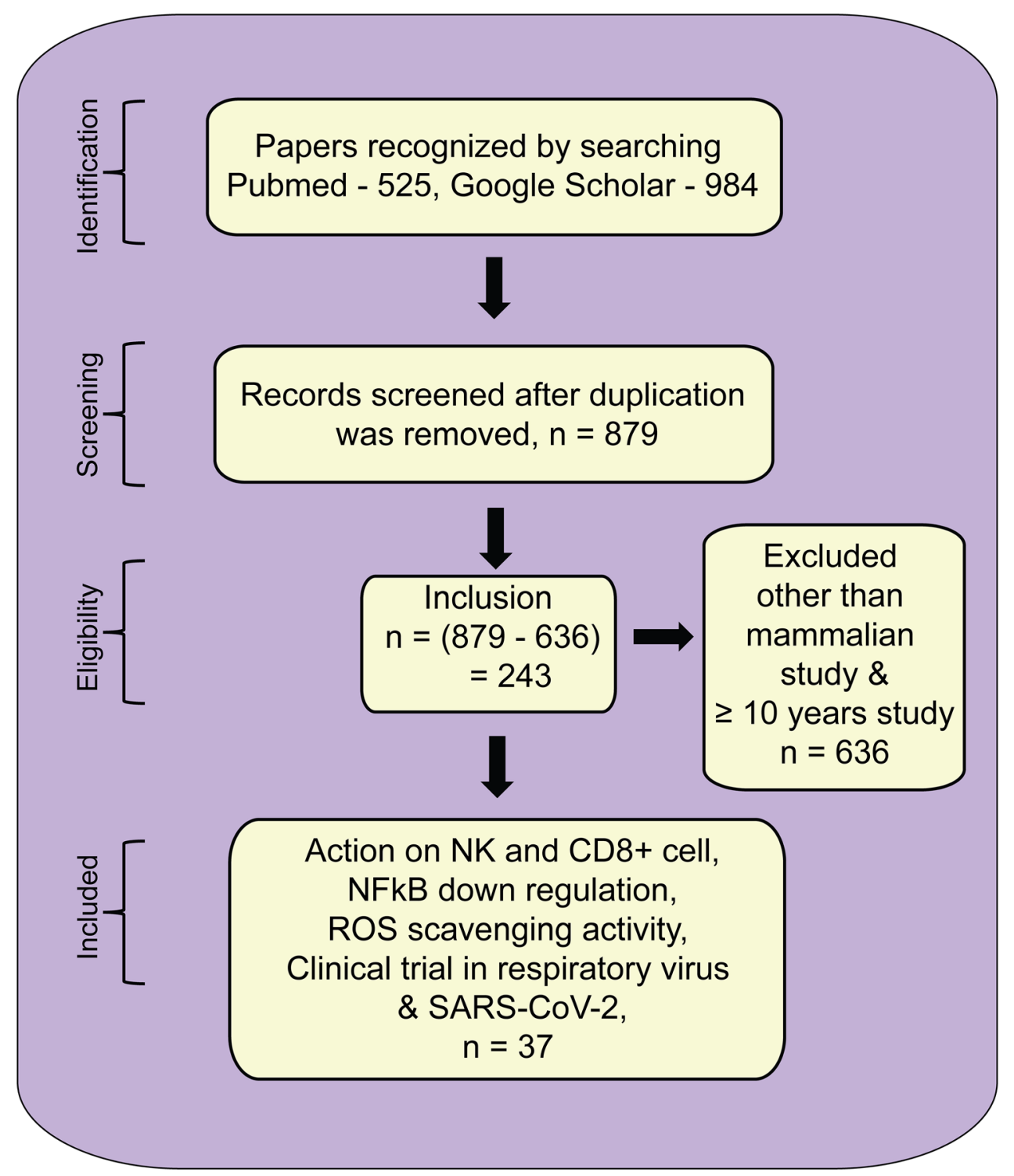

declined levels of hyperactive $\mathrm{T}$ lymphocytes in the peripheral circulation, lymphopenia in patients indicate that $\mathrm{T}$ cells accumulate at the site of infection away from the peripheral circulation to combat viral infection [53]. Cytotoxic T lymphocytes and NK cell population regulate the amelioration of the infection. The number of NK cells and $\mathrm{T}_{\mathrm{C}}$ cells decrease while the expression of NKG2A increases in severe cases. Percentage of IFN- $\gamma$, IL-2 and TNF- $\alpha$ and granzyme B producing NK cells and Tc cells decreases with disease progression, suggesting the collapse of active Tc cells in infected people [68]. The IL 6 and IL 10-induced up regulation of NKG2A on the $\mathrm{NK}$ and naive CD8 + cells cause a sharp decline of the lymphocyte population to produce a versatile cytokine IFN- $\gamma$ resulting in elevated neutrophil population in severe COVID-19 patients [3]. Serum levels of IL6 contribute significantly in disease severity due to its pleiotropic properties. The high mortality rate of Covid-19 patients may be related to the elevated level of IL 6 Amp in aged patients [13] (Fig. S1).

\section{Reactive oxygen species and disease progression}

Several respiratory viruses either cause dysregulation of ROS formation or disrupt antioxidant mechanisms leading to increased recruitment of inflammatory cells at the infection site and subsequent oxidative cell damage respectively. The pathophysiological process of SARSCoV-2 has a link with the overabundance of reactive oxygen species which is very crucial for raised inflammatory cell engagement at the point of infection [44]. According to some studies the commencement of acute lung damage in patients with SARS-CoV-2 infection relies on triggering of reactive oxidative stress mechanism which is integrated with non-specific immunity and turns on 
transcription factors (NF-kB), resulting in the rise of proinflammatory cytokines. It has also been suggested that 3CLpro-induced ROS-activated NF-kB signal transduction pathway, might be considered a principal factor in SARS$\mathrm{CoV}$ associated pathogenicity [44]. The pulmonary surfactant lipids and proteins are adversely affected by resulting inflammation and oxidative stress, thus disrupting gas exchange. The innate host defense mechanism mediated by surfactant-protein is also compromised. ROS is essential in controlling the immunological response correctly for viral infection clearance but an excessive amount of ROS oxidize cellular biomolecules like protein, membrane lipids responsible to destroy not only viral infected cell but also normal cells of the lung, heart resulting multiple organ failure [61]. Elevated Level of ROS implicated injury of lung tissue and epithelial barrier dysfunction with increased susceptibility to secondary infection [15] (Fig. S2).

\section{Efficacy of phytochemicals in COVID-19}

Indian herbal medicines are used by people globally and has been confirmed to reduce the ramifications of flu-like illnesses. Therapy involving phytochemicals may be a worthy, unconventional and safe alternative for treating viral diseases due to their negligible side effects and affordability. Ayurveda system of medicine has proposed a pragmatic plan for managing different stages of COVID-19 patients [41]. Phytochemicals inhibit viral adsorption, cell receptor binding, penetration into the host cell and regulating activation of intracellular signaling pathway [17]. They are reported to be potential in balancing antioxidants and free radicals in our body. We have tried to select certain phytochemicals among numerous, based on their efficacy on the pathways that have been focused in our discussion on the etiology of COVID-19.

A recent study found that Kamferol, curcumin, pterostilbene, bind with the C-terminal of S1 domain. It has also been reported that resveratrol, Fisetin, genistein quercetin, isorhamnetin, luteolin, and apigenin inter react with the S2 domain of spike protein. These compounds have significantly high binding affinity than hydroxychloroquinone. ADME (absorption, distribution, metabolism and excretion) exploration authenticated the attributes of these compounds for use as drugs [40]. A recent study has also revealed the effficacy of phytochemicals by displaying higher docking scores, stronger binding energies, and closer interactions with the conserved catalytic dyad residues (Cys-145 and His-41) of 3CLpro enzyme, than Nelfinavir, Prulifloxacin and Colistin [38]. Thus, it is evident that the phyto-formulations may be employed as potential therapy in COVID-19.
Fig. 2 Schematic representation of possible immunomodulatory pathway in COVID-19 targeted by phytochemicals. Virus sensing can trigger unregulated $\mathrm{NFkB}$ induced inflammatory pathway to produce IL6, TNF $\alpha$, MCP-1. CD8 + contribute upregulation of inflammatory cytokines and chemokines. Reduced NK cell population results less production of IFNs (IFN $\gamma \&$ IFN $\alpha$ ). Cytokine induced inflammation promote accumulation of reactive oxygen species (ROS) and tissue damage in severe disease progression. Abbreviations- IL: Interlukin, IFN: Interferon, MCP-1: Monocyte Chemoattractant Protein -1, GM- CSF: Granulocyte macrophage colony stimulating factor, IP: Interferon gamma induced protein

Phytochemicals have anti-inflammatory and antioxidant properties. They decrease interleukin (IL)-12/IL-18-induced IFN- $\gamma$ production, induces NK cell activity, block the release of proinflammatory cytokines or can act as inhibitors by masking the glycans present on the viral envelope. We have tried to focus on certain phytochemicals and their probable mode of action in modulating the person's immune response to combat the SARS-CoV-2 infection.

\section{Result and discussion}

We have analysed eighteen phytochemicals in respect to our selection criteria. These phytochemicals were curcumin, genistein, garlic extract, resveratrol, ashwagandha extract, tulsi (holy basil), ginseng, kumquat pericarp extract, prostratin, eugenol, capsaicin, eucalyptol, green tea extract, black tea extract, gingerol, cinnamon bark extract, sulforaphane and glycyrrhizin (Fig. 2). Out of these eighteen, eleven were chosen in accordance with their effectiveness on all the four criteria selected. Effectiveness of these phytochemicals on various viral proteins in addition to our specified immunomodulatory pathways have also been mentioned in a tabular form (Table 1). Of these, five phytochemicals (Curcumin, Garlic extract, Green tea extract, Sulforaphane and Ginseng) were chosen based on their application in clinical trial against SARS-CoV-2 or Influenza or respiratory virus (Table 2). The clinical trials of SinaCurcumin which is a registered nanocurcumin formulation of oral dose in Iran (IRC: 1228225765) involving three different parameters of COVID-19 gave significant positive results (Table 3). Curcumin, demethoxycurcumin (DMC) and bisdemethoxycurcumin (BDMC) are three carotenoids in addition to volatile oils, proteins, carbohydrates, and resins, in turmeric ingredients. This needs further trial on a large group to be actually established into a valid drug against SARS-CoV-2. Clinical trial of ashwagandha in combination with Swasari Ras, Giloy Ghanvati, Tulsi Ghanvati and Anu Taila was done on mildly affected and asymptomatic patients (Clinical Trial Registry-India 


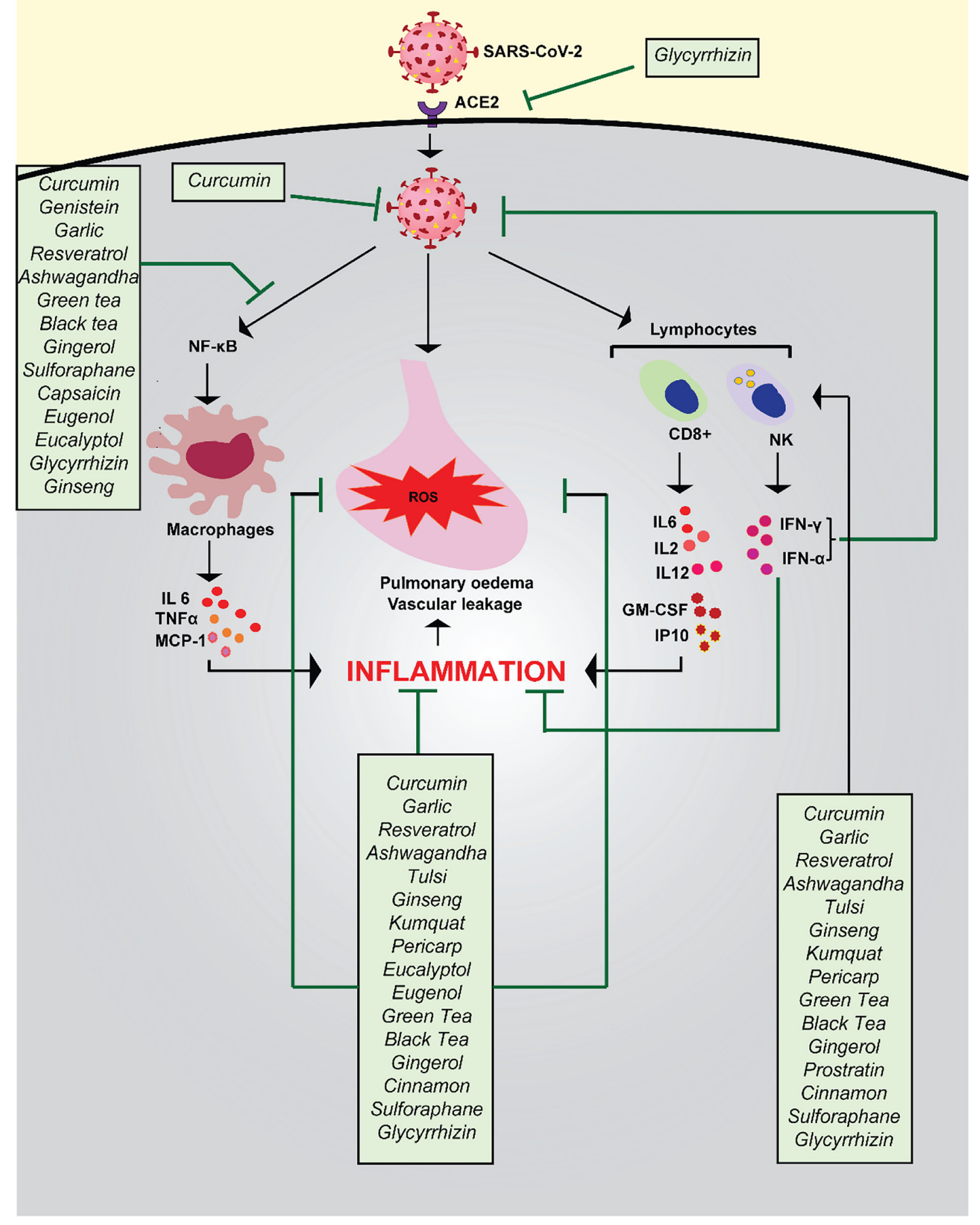


Table 1 Possible therapeutic targets of some phytochemicals in COVID-19

\begin{tabular}{|c|c|c|c|c|c|}
\hline Name & $\begin{array}{l}\text { Chemical nature/active } \\
\text { component }\end{array}$ & Source & $\begin{array}{l}\text { Actions } \\
\text { based on } \\
\text { our } \\
\text { inclusion } \\
\text { criteria }\end{array}$ & Other antiviral effects & References \\
\hline Curcumin & $\begin{array}{l}\text { Diferuloyl methane/ } \\
\text { polyphenols }\end{array}$ & Curcuma longa $\mathrm{L}$ & Yes & $\begin{array}{l}\text { Binds to receptor binding domain (RBD) of } \\
\text { S protein, nucleocapsid protein, } \\
\text { membrane glycoprotein, RNA dependent } \\
\text { RNA polymerase, direct or indirect } \\
\text { inhibition of viral replication machinery } \\
\text { by PI3K/Akt and NF-kB }\end{array}$ & {$[16,59,66]$} \\
\hline Genistein & Isoflavonoid & $\begin{array}{l}\text { Soyabeans, fava } \\
\text { beans, coffee, } \\
\text { Flemingia vestita, } \\
\text { F. macrophylla }\end{array}$ & Yes & Interacts with spike protein's S2 domain & {$[46,64]$} \\
\hline Garlic extract & $\begin{array}{l}\text { Allicin (S-allylcysteine } \\
\text { sulphoxide/ } \\
\text { organosulphur } \\
\text { compounds) }\end{array}$ & Allium sativum & Yes & $\begin{array}{l}\text { Inhibit the ACE2 protein, targeting the } \\
\text { PDB6LU7 protein, the } \mathrm{M}^{\text {pro }} \text { of SARS- } \\
\text { CoV-2, Inhibit multiplication of virus }\end{array}$ & {$[4,54]$} \\
\hline Resveratrol & Polyphenol stilbene & $\begin{array}{l}\text { Grapes, mulberries, } \\
\text { peanuts }\end{array}$ & Yes & $\begin{array}{l}\text { Hinder viral protein synthesis and } \\
\text { expression of genes at different stages } \\
\text { leading to prevention of viral replication }\end{array}$ & {$[26,35,43,65]$} \\
\hline $\begin{array}{l}\text { Ashwagandha } \\
\text { Extract }\end{array}$ & $\begin{array}{l}\text { Alkaloids and steroidal } \\
\text { lactones steroidal } \\
\text { alkaloids, withaferin A } \\
\text { and withanolide D }\end{array}$ & Withania somnifera & Yes & $\begin{array}{l}\text { Increased the expression of Th1 cytokines, } \\
\text { Bind to the substrate-binding pocket of } \\
\text { SARS-CoV-2 Mpro }\end{array}$ & {$[20,45,55]$} \\
\hline $\begin{array}{c}\text { Green tea } \\
\text { extract }\end{array}$ & $\begin{array}{l}\text { Polyphenols } \\
\text { (epigallocatech in } \\
\text { 3-gallate) }\end{array}$ & Camellia sinensis & Yes & $\begin{array}{l}\text { Agglutination and acidification effects on } \\
\text { endosome \& lysosomes, inhibits viral } \\
\text { replication }\end{array}$ & {$[19,28,36]$} \\
\hline $\begin{array}{c}\text { Black tea } \\
\text { extract }\end{array}$ & $\begin{array}{l}\text { Polyphenols (theaflavin- } \\
\text { 3,3'-digallate) }\end{array}$ & Camellia sinensis & Yes & $\begin{array}{l}\text { Theaflavins- } 1 \text {, Theaflavins- } 2 \text { and } \\
\text { Theaflavins- } 3 \text { were found to supress the } \\
\text { SARS-CoV-2 replication by targeting } \\
\text { RNA-dependent RNA polymerase } \\
\text { (RdRp) }\end{array}$ & {$[25,27]$} \\
\hline Gingerol & Phenol & Ginger & Yes & & {$[2,10]$} \\
\hline Sulforaphane & Isothiocyanate & $\begin{array}{l}\text { Broccoli, green } \\
\text { cabage, red } \\
\text { cabbage, turnip }\end{array}$ & Yes & $\begin{array}{l}\text { Block the bronchoconstrictor } \\
\text { hyperresponsiveness, arrest ARDS, } \\
\text { activates Nrf } 2 \text { and reinstate the age- } \\
\text { related lapse of Th1 immunity }\end{array}$ & {$[7,24,50]$} \\
\hline Glycyrrhizin & Triterpene saponin & $\begin{array}{l}\text { Glycirrhiza glabra } \\
\text { roots }\end{array}$ & Yes & $\begin{array}{l}\text { Binds ACE2, inhibits thrombin and } \\
\text { alleviation of airway exudates, induces } \\
\text { exogenous interferon, upregulation of } \\
\text { p38, JNK and redox-sensitive signalling } \\
\text { events }\end{array}$ & {$[29,63]$} \\
\hline Ginseng & Ginsenosides, saponin & Panax ginseng & Yes & & {$[22,52]$} \\
\hline
\end{tabular}

+ Denotes Activation,-Denotes Inhibition

PI3K (phosphoinositide 3-kinase), NFkB (Nuclear Factor kappa-light-chain-enhancer of activated B cell), ACE2 (Angiotensin Converting Enzyme 2), GABA (Gamma-Aminobutyric Acid), Intercellular Adhesion Molecule (ICAM)-1, Vascular Cell Adhesion Molecule (VCAM)-1, JNK (c-Jun N-terminal kinase). M Pro (main Protease)

(CTRI) (CTRI No. CTRI/2020/05/025273). It was found that the time of health restoration was brought down in response to the treatment and reduced serum levels of hsCRP and pro-inflammatory markers, interleukin-6 (IL-6) and tumor necrosis factor alpha (TNF- $\alpha$ ) [9]. All these observations provide a constructive lead towards their usage as drugs or dietary supplement in a dose specific manner for managing the progression of this viral disease.

Phytochemicals have a great potency to minimize the imbalance between free radicals and antioxidants where inflammatory cells are responsible for promoting pathogenesis. They are highly effective in arresting 
Table 2 List of Some potential phytochemicals that have the possibility of use as therapeutic agents against SARS-CoV-2 in line with the evidences of their clinical trials ( Source PUBMED)

\begin{tabular}{|c|c|c|c|c|}
\hline Phytochemical & Clinical Trial & Formulation/ dosage & Result & References \\
\hline Curcumin & $\begin{array}{l}\text { SARS-CoV-2 } \\
\text { Phase II }\end{array}$ & ArtemiC as dietary supplement & Not yet published & {$[42]$} \\
\hline Garlic Extract & $\begin{array}{l}\text { Conducted on } \\
\text { common cold } \\
\text { virus }\end{array}$ & $\begin{array}{l}120 \text { healthy subjects were taken to record the } \\
\text { efficacy of aged garlic extract supplementation } \\
(2.56 \mathrm{~g} / \mathrm{day}) \text { on proliferation of immune cells } \\
\text { and flu symptoms of common cold Virus }\end{array}$ & $\begin{array}{l}\text { The group consuming the aged garlic } \\
\text { extract had reduced severity and less } \\
\text { symptoms were noticed }\end{array}$ & {$[33]$} \\
\hline $\begin{array}{l}\text { Green tea } \\
\text { extract } \\
\text { (catechins) }\end{array}$ & Influenza infection & Gargling for 90 days & No conclusive evidence & {$[14]$} \\
\hline Sulforaphane & Influenza virus & BSH for 4 consecutive days & $\begin{array}{l}\text { Increases virus-induced peripheral } \\
\text { blood NK cell granzyme B } \\
\text { production }\end{array}$ & [31] \\
\hline Ginseng & $\begin{array}{l}\text { Acute Respiratory } \\
\text { Infection } \\
\text { Randomized, } \\
\text { double-blind, } \\
\text { placebo controlled } \\
\text { clinical trial }\end{array}$ & $\begin{array}{l}100 \text { subjects were involved in this study and } \\
\text { randomly assigned to the KRG and placebo } \\
\text { group KRG dose } 3.0 \text { g/day for } 4 \text { weeks as } \\
\text { compared to placebo group }\end{array}$ & $\begin{array}{l}\text { Statistically significant }(\mathrm{P}=0.034) \\
\text { results regarding the occurence of } \\
\text { ARI were found to be lower in KRG } \\
\text { group }\end{array}$ & {$[23]$} \\
\hline
\end{tabular}

BSH: Broccoli Sprout Homogenate, URTIs: Upper Respiratory Tract Infections, ARI; Acute Respiratory Infection, KRG: Korean Red Ginseng

inflammatory disorders by lowering the synthesis of proinflammatory cytokines. The phytochemicals have shown the presence of significant anti-inflammatory characteristic based on their scoring functions and together with the possibility of being formulated as drugs based on their physico-chemical properties, makes way for their future investigation in the production of innovative compounds which could prohibit the binding and fusion of S1 and S2 proteins of SARS-CoV-2. On the basis of recent evidences on the action of phytochemicals against inhibition of SARS-CoV-2 3CLPro activity and hence viral replication, possible role of the phytochemicals as potential drugs in COVID-19 has been intensified. The physical and chemical properties of the phytochemicals like melting point, molecular weight, affinity to lipids and their chemical configuration affect the method of drug formulation so as to make it more permeable. Nanomedicines that are highly target specific, evade cellular defense reaction, balance oxidative stress and can release the drug in reaction to specific signals can be efficacious for this purpose.

The antiinflammatory, immunostimulatory, antiasthmatic, anticold, and antioxidative properties of phytochemicals make them very popular choice in the diet of the pregnant women like cowpea, garlic, turnip, tomatoes, guava, cauliflower, drumstick leaves [21]. There have been positive reports of antioxidative activity of garlic based on random double blind clinical trials taking $400 \mathrm{mg}$ of garlic and $1 \mathrm{mg}$ of allicin per day for nine weeks in pregnant women having no side effects [1]. Obesity has been an important factor leading to many comorbidities as Type I diabetes, cardiovascular diseases, kidney ailments etc. Phytochemicals have been shown to be effective in dealing with these conditions, however there have been reports for toxic effects in case of long term use of glycyrrhizin, curcumin, green tea and garlic extract [62]. Glycyrrhizin has been reported to cause physiological complications related to heart and blood vascular diseases when consumed daily at low doses [34, 47]. Further over consumption of green tea can cause kidney ailments [5], prolonged consumption of garlic at $250-1000 \mathrm{mg} / \mathrm{kg}$ dose can create adverse effects in lung and liver tissues [39], while continuous intake of curcumin at 0.9 to $3.6 \mathrm{~g}$ /day can give rise to diarrhea and nausea respectively [49]. However, there are reports of Curcumin at doses of $500 \mathrm{mg}$ twice a day for 30 days orally was found to be nontoxic for humans [48]. It is very important to formulate correct doses for the consumption of these functional food plants to evade any sort of adverse reactions. Therefore, more long-term clinical trials become mandatory for finding a safe dose. Drugs in the form of nanoformulations such as green nanoparticles or carrier nanodrug or designing site specific nano medicines can be the way out so that high affectivity can be procured in spite of a low dose of the phyto formulation. Nanoparticle mediated drug delivery is a protected means of medicine application in pregnant women because of its low chance of interfering with the development of foetus [18]. 
Table 3 Clinical trials of Curcumin against SARS-Cov-2 in Iran approved by the Research Ethics Committee of Tabriz University of Medical Sciences (IR.TBZMED.REC.1398.1314)

\begin{tabular}{|c|c|c|c|c|c|}
\hline Phytochemical & Formulation & Dosage & Clinical Trial & Result & References \\
\hline \multirow[t]{4}{*}{ Curcumin } & \multirow[t]{4}{*}{$\begin{array}{l}\text { SinaCurcumin (Exir } \\
\text { Nano, Tehran, } \\
\text { Iran) Soft gelatin } \\
\text { capsules } \\
\text { containing } \\
\text { curcuminoids as } \\
\text { nanomicelles }\end{array}$} & $\begin{array}{l}\text { Two } 40 \mathrm{mg} \text { soft gel } \\
\text { Capsules twice daily for } \\
14 \text { days }\end{array}$ & $\begin{array}{l}\text { Non randomized, open } \\
\text { labelled trial } 20 \text { COVID- } \\
19 \text { patients in age group of } \\
18 \text { to } 75 \text { years with mild } \\
\text { to moderate disease } \\
\text { symptoms were taken in } \\
\text { treated and placebo group } \\
\text { respectively }\end{array}$ & $\begin{array}{l}\text { Significant recovery rate } \\
(47.6 \%) \text { was observed in } \\
\text { treated compared to the } \\
\text { control group }(15 \%) \text {. } \\
\text { Also, no degeneration } \\
(40 \%) \text { of patients was } \\
\text { observed in the treated } \\
\text { group }\end{array}$ & {$[30]$} \\
\hline & & $\begin{array}{l}\text { One } 80 \mathrm{mg} \text { capsule twice } \\
\text { daily for } 21 \text { days }\end{array}$ & \multirow{2}{*}{$\begin{array}{l}\text { Randomized, double-blind- } \\
\text { placebo controlled trial } \\
\text { study } 40 \text { severe COVID- } \\
19 \text { patients and } 40 \text { mild } \\
\text { cases of COVID-19 were } \\
\text { chosen. The severe } \\
\text { patients were divided into } \\
\text { treated and placebo group } \\
\text { each consisting of } 20 \\
\text { individuals. } 40 \text { healthy } \\
\text { individuals were involved } \\
\text { in the trial }\end{array}$} & $\begin{array}{l}\text { T regulatory cells were } \\
\text { elevated significantly in } \\
\text { moderately infected and } \\
\text { serious patients and also } \\
\text { alleviate the mortality rate } \\
\text { in severe patients. }\end{array}$ & \multirow[t]{2}{*}{ [51] } \\
\hline & & & & $\begin{array}{l}\text { FoxP3, TGF- } \beta \text {, IL-10, and } \\
\text { IL-35 factors expression } \\
\text { were notably upregulated } \\
\text { in Nanocurcumin-treated } \\
\text { both moderate and serious } \\
\text { patients after treatment } \\
\text { compared to before } \\
\text { treatment; while, no } \\
\text { substantial changes were } \\
\text { found in the placebo- } \\
\text { treated group }\end{array}$ & \\
\hline & & $\begin{array}{l}160 \mathrm{mg}(40 \mathrm{mgx} 4) \text { Daily for } \\
14 \text { days }+ \text { Betaferon } \\
300 \mu \mathrm{g} \text { subcutaneously } \\
\text { every Other day until } \\
5 \text { days, Bromhexine } 8 \mathrm{mg} \\
\text { tablets every } 8 \mathrm{~h} \text {, and } \\
\text { Atrovastatin } 40 \mathrm{mg} \text { daily }\end{array}$ & $\begin{array}{l}\text { Randomized, double blind } \\
\text { placebo controlled study } \\
\text { where } 40 \text { COVID-19 } \\
\text { patients in the age group } \\
\text { of } 19-69 \text { years were } \\
\text { divided into treated and } \\
\text { placebo group of } 20 \\
\text { subjects each } 40 \text { healthy } \\
\text { people were also included } \\
\text { in the study }\end{array}$ & $\begin{array}{l}\text { Statistically significant } \\
\text { augmentation in almost all } \\
\text { indicators displayed in } \\
\text { Nano-curcumin group, } \\
\text { including fever, cough and } \\
\text { dyspnea were significantly } \\
\text { subsided }(P<0.0001) \text {. } \\
\text { IL1- } \beta \text { and IL-6 mRNA } \\
\text { expression were decreased } \\
\text { substantially in the treated } \\
\text { group }\end{array}$ & [56] \\
\hline
\end{tabular}

Our observation regarding the potential act of phytochemicals as therapeutic agents in managing COVID-19 is further strengthened by the evidences from clinical trials of some phytochemicals like curcumin and ashwagandha against SARS-CoV-2 have further strengthened their beneficial use in boosting immunity against this virus. The phytochemicals like Garlic extract, Green tea extract, Sulforaphane and Ginseng applied in the clinical trial against virus causing respiratory diseases also indicate towards a possibility for their application in managing SARS-CoV-2. The clinical trial of Black Tea extract and Glycyrrhizin is also recommended by us keeping in view their use in Indian perspective, pointing towards their prospective role in challenging this virus. Further in vitro and in vivo studies regarding their combinatorial and dose specific effects should be undertaken so as to formulate adjuvant drugs to tackle this dreaded viral disease. This will definitely go a long way in benefiting our country as far as its sizeable population is concerned and the continuance of the vaccination process with its respect.

Acknowledgements The authors owe their gratitude to Rishi Bankim Chandra College, Naihati, 24 Pgns (N), West Bengal, India.

\section{References}

1. Aalami-Harandi R, Karamali M, Asemi Z. The favorable effects of garlic intake on metabolic profiles, hs-CRP, biomarkers of oxidative stress and pregnancy outcomes in pregnant women at risk for pre-eclampsia: Randomized, double-blind, placebo-controlled trial. J Matern Fetal Neonatal Med. 2015;28(17):2020-7. https://doi.org/10.3109/14767058.2014.977248. 
2. Amri M, Boukoffa CT. In vitro anti-hydatic and immunomodulatory effects of ginger and [6]-gingerol. Asian Pac J Trop Med. 2016;9(8):749-56. https://doi.org/10.1016/j.apjtm.2016.06.013.

3. Antonioli L, Fomai M, Pellegrini C and Blandizzi C. NKG2A and COVID-19 another brick in the wall. Cell Mol Immunol. 2020; 672-74. https://doi.org/10.1038/s41423-020-0450-7

4. Badr GM and Al-Mulhim JA. The protective effect of aged garlic extract on nonsteroidal anti-inflammatory drug-induced gastric inflammations in male albino rats. Evid Based Complementary and Altern Med. 2014; Article ID 759642, 9: 2014. doi: https:// doi.org/10.1155/2014/759642.

5. Bedrood Z, Rameshrad M, Hosseinzadeh H. Toxicological effects of Camellia sinensis (green tea): a review. Phytother Res. 2018;32:1163-80. https://doi.org/10.1002/ptr.6063.

6. Bell TJ, Brand OJ, Morgan DJ, Salek-Ardakani S, Jagger C, Fujimori T, Cholewa L, Tilakratna V, Ostling J, Thomas M, Day AJ, Snelgrove RJ, Hussel T. Defective lung function following influenza virus is due to prolonged, reversible hyaluronan synthesis. Matrix Biol. 2018;80:14-28. https://doi.org/10.1016/j. matbio.2018.06.006.

7. Brown RH, Reynolds C, Brooker A, Talalay P, and Fahey JW. Sulforaphane Improves the bronchoprotective response in asthmatics through Nrf2-mediated gene pathways. Respir Res. 2015; 16(1): 106. Doi.https://doi.org/10.1186/s12931-015-0253-z.

8. Channappanavar R, Fehr AR, Vijay R, Mack M, Zhao J, Meyerholz DK, Perlman S. Dysregulated Type I interferon and inflammatory monocyte-macrophage responses cause lethal pneumonia in SARS-CoV-infected mice. Cell Host Microbe. 2016;19(2):181-93. https://doi.org/10.1016/j.chom.2016.01.007.

9. Devpura G, Balvir S. Tomar BS, Deepak Nathiya D, Abhishek Sharma A, Bhandari D, Haldar S, et al. Randomized placebocontrolled pilot clinical trial on the efficacy of ayurvedic treatment regime on COVID-19 positive patients. Phytomedicine 84 (2021) 153494. https://doi.org/10.1016/j.phymed.2021.153494.

10. Dugasani S, Pichika MR, Nadarajah VD, Balijepalli MB, Tandra S, Korlakunta JN. Comparative antioxidant and anti-inflammatory effects of [6]-gingerol, [8]-gingerol, [10]-gingerol and [6]shogaol. J Ethnopharmacol. 2010;127(2):515-20. https://doi.org/ 10.1016/j.jep.2009.10.004.

11. Eguchi S, Kawai T, Scalia R, Rizzo V. Understanding angiotensin II Type 1 receptor signaling in vascular pathophysiology. Hypertension. 2018; 71(5): 804-10. https://doi.org/10.1161/ HYPERTENSIONAHA.118.10266

12. Hällgren R, Samuelsson T, Laurent TC, Modig J. Accumulation of hyaluronan (hyaluronic acid) in the lung in adult respiratory distress syndrome. Am Rev Respir Dis. 1989;139(3):682-7. https://doi.org/10.1164/ajrccm/139.3.682.

13. Hirano T, Murakami M. COVID-19: a new virus, but a familiar receptor and cytokine release syndrome. Immunity. 2020;52(5):731-3. https://doi.org/10.1016/j.immuni.2020.04.003.

14. Ide K, Yamada H, Matsushita K, Ito M, Nojiri K, Toyoizumi K, Matsumoto K, Sameshima Y. Effects of green tea gargling on the prevention of influenza infection in high school students: a randomized controlled study. PLoS ONE. 2014;9(5): e96373. https:// doi.org/10.1371/journal.pone.0096373.

15. Ivanov $\mathrm{AV}$, Bartosch $\mathrm{B}$, and Isaguliants MG. Oxidative stress in infection and consequent disease. Oxid Med. 2017; 1-3. https:// doi.org/10.1155/2017/3496043

16. Jena AB, Kanungo N, Nayak V, Chainy GBN, Dandapat J. Catechin and Curcumin Interact with Corona (2019-NCoV/ SARS-CoV2) Viral S Protein and ACE2 of human cell membrane: insights from computational study and implication for intervention. Preprint In Review. 2020. https://doi.org/10.21203/ rs.3.rs-22057/v1.
17. Kapoor R, Sharma B, Kanwar SS. Antiviral phytochemicals: an overview. Biochem Physiol 2017; 6:220. https://doi.org/10.4172/ 2168-9652.1000220

18. Keelan JA, Leong JW, Ho D. Iyer KS Therapeutic and safety considerations of nanoparticle-mediated drug delivery in pregnancy. Nanomedicine (Lond). 2015;10(14):2229-47. https://doi. org/10.3346/jkms.2012.27.

19. Kim YH, Won YS, Yang X, Kumazoe M, Yamashita S, Hara A, Takagaki A, Goto K, Nanjo F, Tachibana F. Green tea catechin metabolites exert immunoregulatory effects on $\mathrm{CD} 4{ }^{+} \mathrm{T}$ cell and natural killer cell activities. J Agric Food Chem. 2016;64(18):3591-7. https://doi.org/10.1021/acs.jafc.6b01115.

20. Kumar V, Dhanjal JK, Kaul SC, Wadhwa R, Sundar D. Withanone and caffeic acid phenethyl ester are predicted to interact with main protease $\left(\mathrm{M}^{\mathrm{pro}}\right)$ of SARS-CoV-2 and inhibit its activity. J Biomol Struct Dyn. 2020;1:1-13. https://doi.org/10.1080/ 07391102.2020.1772108.

21. Laxmi D, Prasanna M, Baskar R. Phytochemicals from nine plants beneficial for pregnant women. IJPR. 2014;4(4):166-74. https://doi.org/10.7439/ijpr.v4i4.137.

22. Lee JS, Lee YN, Lee YT, Hwang HS, Kim KH, Ko EJ, Kim MC, Kang SM. Ginseng protects against respiratory synctial virus by modulating multiple immune cells and inhibiting viral replication. Nutrients. 2015;7(2):1021-36. https://doi.org/10.3390/ nu7021021.

23. Lee CS, Lee JH, Oh M, Choi KM, Jeong MR, Park JD. Preventive effect of Korean Red ginseng for acute respiratory illness: a randomised and double blind clinical trial. J Korean Med Sci. 2012;27:1472-8. https://doi.org/10.3346/jkms.2012.27.

24. Li Z, Liu Y, Fanf Z, Yang L, Zhuang M, Zhang Y. Natural sulforaphane from broccoli seeds against Influenza A virus replication in MDCK cells. Nat Prod Commun. 2019;1-8. https:// doi.org/10.1177/1934578X19858221.

25. Li YW, Zhang Y, Zhang L, Li X, Yu JB, Zhang HT, Tan BB, Jiang LH, Wang YX, Liang Y, Zhang XS, Wang WS, Liu HG. Protective effect of tea polyphenol on renal ischemia/reperfusion injury via suppressing the activation of TLR4/NF-kB p65 signal pathway. Gene. 2014;542(1):46-51. https://doi.org/10.1016/j. gene.2014.03.021.

26. Lu CC, Chen JK. Resveratrol enhances Perforin expression and NK cell cytotoxicity through NKG2D-pathway. J Cell Physiol. 2010;223:343-51. https://doi.org/10.1002/jcp.22043.

27. Lung J, Lin YS, Yang YH, Chou YL, Shu LH, Cheng YC, Liu $\mathrm{HT}, \mathrm{Wu} \mathrm{CY}$. The potential chemical structure of anti-SARSCoV-2 RNA-dependent RNA polymerase. J Med Virol. 2020;25761. https://doi.org/10.1002/jmv.25761.

28. Marinovic MP, Morandi AC, Otton R. Green tea catechins alone or in combination alter functional parameters of human neutrophils via suppressing the activation of TLR-4/NFkappaB p65 signal pathway. Toxicol In Vitro. 2015;29:1766-78. https://doi. org/10.1016/j.tiv.2015.07.014.

29. Michaelis M, Geiler J, Naczk P, Sithisarn P, Leutz A, Doerr HW, Cinatl J Jr. Glycyrrhizin exerts antioxidative effects in H5N1 influenza A virus-infected cells and inhibits virus replication and pro-inflammatory gene expression. PLoS ONE. 2011;6: e19705. https://doi.org/10.1371/journal.pone.0019705.

30. Moghaddam NS, Salari S, Hejazi S, Amini M, Taherzadeh Z, Eslami $S$, et al. Oral nano-curcumin formulation efficacy in management of mild to moderate hospitalized coronavirus disease-19 patients: an open label nonrandomized clinical trial. Phytother Res. 2021;35:2616-23. https://doi.org/10.1002/ptr. 7004.

31. Müller L, Meyer M, Bauer RN, Zhou H, Zhang H, Jones S, Robinette C, Noah TL, Jaspers I. Effect of broccoli sprouts and live attenuated influenza virus on peripheral blood natural killer 
cells: a randomized, double-blind study. PLoS One. 2016; 28; 11(1): e0147742. https://doi.org/10.1371/journal.pone.0147742

32. Murakami M, Kamimura D, Hirano T. Pleiotropy and specificity: insights from the interleukin 6 family of cytokines. Immunity. 2019; 50(4): 812-31. https://doi.org/10.1016/j.immuni.2019.03. 027

33. Nantz MP, Rowe CA, Muller CE, Creasy RA, Stanilka JM, Percival SS. Supplementation with aged garlic extract improves both NK and $\gamma \delta$-T cell function and reduces the severity of cold and flu symptoms: a randomized, double-blind, placebo-controlled nutrition intervention. Clin Nutr. 2012;31(3):337-44. https://doi.org/10.1016/j.clnu.2011.11.019.

34. Nazari S, Rameshrad M, Hosseinzadeh H. Toxicological effects of Glycyrrhiza glabra (licorice): a review. Phytother Res. 2017;31:1635-50. https://doi.org/10.1002/ptr.5893.

35. Pan Y, Zhang H, Zheng Y, Zhou J, Yuan J, Yu Y, Wang J. Resveratrol exerts antioxidant effects by activating SIRT2 to deacetylate Prx1. Biochemistry US. 2017;56:6325-8. https://doi. org/10.1021/acs.biochem.7b00859.

36. Park HJ, Lee JY, Chung MY, Park YK, Bower AM, Koo SI, Giardina C, Bruno RS. Green tea extract suppresses NFאB activation and inflammatory responses in diet-induced obese rats with nonalcoholic steatohepatitis. Nutr J. 2012;142(1):57-63. https://doi.org/10.3945/jn.111.148544.

37. Phur J, Weng L, Ling L, Egi M, Lim CM, Divatia JV, Shrestha BR, Arabi YM, Ng J, Gomersall CD, Nishimura M, Koh Y, Du B. Intensive care of corona virus disease 2019 (COVID 19): challenges and recommendations. Lancet. 2020;8(5):506-17. https:// doi.org/10.1016/S2213-2600(20)30161-2.

38. Qamar MT, Alqahtani SM, Alamri MA, Chen LL. Structural basis of SARS-CoV-2 3CLpro and anti-COVID-19 drug discovery from medicinal plants. J Pharm Anal. 2020; S2095177920301271. https://doi.org/10.1016/j.jpha.2020.03.009

39. Rana SV, Pal R. Vaiphei K, Sharma SK, Ola, RP. Garlic in health and disease. Nut Res Rev. 2011; 24: 60-71. doi: https://doi.org/ 10.1017/S0954422410000338.

40. Rane JS, Chatterjee A, Kumar A, Ray S. Targeting SARS-CoV-2 spike protein of COVID-1[9 with naturally occurring phytochemicals: an in silco study for drug development. Preprint, 2020. https://doi.org/10.26434/chemrxiv.12094203.v1

41. Rastogi S, Pandey DN, Singh RH. Covid-19 pandemic; A pragmatic plan for ayurveda intervention. J Ayurveda Integr Med. 2020; In press. https://doi.org/10.1016/j.jaim.2020.04.002

42. Ethics Committee Approval Received for Phase II Clinical Trial on Patients Diagnosed with COVID-19 https://wcsecure.weblink. com.au/pdf/MXC/02225823.pdf

43. Ren Z, Wang L, Cui J, Huoc Z, Xue J, Cui H, Mao Q, Yang R. Resveratrol Inhibits NF-kB signaling through suppression of $\mathrm{p} 65$ and Ikappa B kinase activities. Pharmazie. 2013;68(8):689-94 (PMID: 24020126).

44. Roche LD, and Mesta F. Oxidative stress as key player in severe acute respiratory syndrome coronavirus (SARS-CoV) infection. Arch Med Res. 2020; S0188440920305403. https://doi.org/10. 1016/j.arcmed.2020.04.019

45. Shah R, Singh R, Sarangi U, Saxena N, Chaudhary A, Kaur G, Kaul SC, Wadhawa R. Combinations of ashwagandha leaf extracts protect brain-derived cells against oxidative stress and induce differentiation. PLoS ONE. 2015;10(3): e0120554. https:// doi.org/10.1371/journal.pone.0120554.

46. Smith NB, Dilger RN. Immunomodulatory potential of dietary soyabean-derived isoflavones and saponins in pigs. J Anim Sci. 2018;96:1288-304. https://doi.org/10.1093/jas/sky036.

47. Snafi-Al AE. Glycyrrhiza glabra: a phytochemical and pharmacological review. IOSR J Pharm. 2018;8:01-17. https://doi.org/ $10.5772 / 58918$
48. Soleimani V, Sahebkar A, Hosseinzade H. Turmeric (Curcuma longa) and its major constituent (curcumin) as nontoxic and safe substances: Review. Phytother Res. 2018;32(6):985-95. https:// doi.org/10.1002/ptr.6054.

49. Somasundaram S, Edmund NA, Moore DT, Small GW, Shi YY, Orlowski RZ, et al. Dietary curcumin inhibits chemotherapy induced apoptosis in models of human breast cancer. Cancer Res. 2002;62:3868-75.

50. Sun Z, Niu Z, Wu S, and Shan S. Protective mechanism of sulforaphane in Nrf2 and anti-lung injury in ARDS rabbits. Exp Ther Med. 2018; 4911-915. doi: https://doi.org/10.3892/etm. 2018.6036

51. Tahmasebi S, Saeed BQ, Temirgalieva E, Yumashev AV, ElEsawi MA, Navashenaq JG, et al. Nanocurcumin improves Treg cell responses in patients with mild and severe SARS-CoV2. Life Sci. 2021;276: 119437. https://doi.org/10.1016/j.lfs.2021.119437.

52. Takeda K, and Okumura K. Interferon- $\gamma$-mediated natural killer cell activation by an aqueous Panax Ginseng Extract. Evid. Based Complementary Altern. 2015; 1-11. https://doi.org/10. 1155/2015/603198

53. Tay MZ, Poh CM, Rénia L, MacAry PA, Ng LFP. The Trinity of COVID-19: immunity, inflammation and intervention. Nat Rev Immunol. 2020;20(6):363-74. https://doi.org/10.1038/s41577020-0311-8.

54. Thuy BTP, My TTA, Hai NTT, Hieu LT, Hoa TT, Loan HTP, Triet NT, Anh TTV, Quy PT, Tat PV, Hue NV, Quang DT, Trung NT, Tumg VT, Hyung LK, Nhung NTAal. Investigation into SARS-CoV-2 Resistance of Compounds in Garlic Essential Oil. ACS Omega, no. 2020; 5(14): 8312-320. doi: https://doi.org/10. 1021/acsomega.0c00772

55. Trivedi MK, Mondal SC, Gangwar M, Jana S. Effect of a novel ashwagandha-based herbomineral formulation on pro-inflammatory cytokines expression in mouse splenocyte cells: a potential immunomodulator. Pharmacogn Mag. 2017;13(49):90. https:// doi.org/10.4103/0973-1296.197709.

56. Valizadeh H, Abdolmohammadi-vahid S, Danshina S, Ziya Gencer M, Ammari A, Sadeghi A, et al. Nano-curcumin therapy, a promising method in modulating inflammatory cytokines in COVID-19 patients. Int Immunopharmacol. 2020;89: 107088. https://doi.org/10.1016/j.intimp.2020.107088.

57. Vellingiri B, Jayaramayya K, Iyer M, Narayanasamy A, Govindasamy N, Giridharan B, Ganesan S, Venugopal A, Venkatesan D, Ganesan H, Rajagopalan K, Rahman PKSM, Cho SG, Senthilkumar N, Subraniyam MD. COVID-19: a promising cure for the global panic. Sci Total Environ. 2020;725: 138277. https://doi.org/10.1016/j.scitotenv.2020.138277.

58. Walls AC, Park YJ, Tortorici MA, Wall A, McGuire AT, Veesler D. Structure, function, and antigenicity of the SARS-CoV-2 spike glycoprotein. Cell. 2020;180:281-92. https://doi.org/10.1016/j. cell.2020.02.058

59. Wang X, An X, Wang X, Bao C, Li J, Yang D, Bai C. Curcumin ameliorated ventilator-induced lung injury in rats. Biomed Pharmacother. 2018; 98: 754-761. doi:https://doi.org/10.1016/j. biopha.2017.12.100

60. Wang D, Hu B, Hu C, Zhu F, Liu X, Zhang J, Wang B, Xiang H, Cheng Z, Xiong Y, Zhao Y, Li Y, Wang X, Peng Zl. Clinical Characteristics of 138 Hospitalized Patients With 2019 Novel Coronavirus-Infected Pneumonia in Wuhan, China. JAMA. 2020; 323. https://doi.org/10.1001/jama.2020.1585

61. Wang JZ, Zhang RY and Bai J. An anti-oxidative therapy for ameliorating cardiac injuries of critically ill COVID-19-infected patients. Int J Cardiol. 2020; 312: 137-38. https://doi.org/10. 1016/j.ijcard.2020.04.009

62. Yang F, Zhang Y, Tariq A, Jiang X, Ahmed Z, Zhihao Z, Idrees M, Azizullah A. Adnan M, Bussmann RW. Food as medicine: a possible preventive measure against coronavirus disease 
(COVID-19). Phytother Res. 2020; 1-13. DOI: https://doi.org/10. 1002/ptr.6770.

63. Yao L, Sun T. Glycyrrhizin administration ameliorates Streptococcus aureus-induced acute lung injury. Int Immunopharmacol. 2019;70:504-11. https://doi.org/10.1016/j.intimp.2019.02.046.

64. Yoon G, Park S. Antioxidant action of soy isoflavones on oxidative stress and antioxidant enzyme activities in exercised rats. Nutr Res Pract. 2014;8(6):618-24. https://doi.org/10.4162/ nrp.2014.8.6.618.

65. Zang, N, Li, S, Li,W, Xie, X, Ren, L, Long, X, Xie J, Deng Yu, Fu Z, Xu F, Liu E. Resveratrol suppresses persistent airway inflammation and hyperresponsivess might partially via nerve growth factor in respiratory syncytial virus-infected mice. Int Immunopharmacol. 2015; 28: 121-128. DOI: https://doi.org/10. 1016/j.intimp.2015.05.031
66. Zhang Y, Liang D, Dong L, Ge X, Xu F, Chen W, Dai Y, Li H, Zou P, Yang S, Liang G. Antiinflammatory effects of novel curcuminb analogs in experimental acute lung injury. Respir Res. 2015;16:43. https://doi.org/10.1186/s12931-015-0199-1.

67. Zhao Y, Zhao Z, Wang Y, Zhou Y, Ma Y, Zuo W. Single-cell RNA expression profiling of ACE2, the putative receptor of Wuhan 2019-nCov. BioRxiv, 2020; https://doi.org/10.1101/2020. 01.26.919985

68. Zheng M, Gao Y, Wang G, Song G, Liu S, Sun D, Xu Y, Tian Z. Functional exhaustion of antiviral lymphocytes in COVID-19 patients. Cell Mol Immunol. 2020; 17: 5533-35; https://doi.org/ 10.1038/s41423-020-0402-2

Publisher's Note Springer Nature remains neutral with regard to jurisdictional claims in published maps and institutional affiliations. 